\section{Keeping Water and Nutrients in the Florida Citrus Tree Root Zone}

\author{
Thomas A. Obreza ${ }^{1,3}$ and Arnold Schumann ${ }^{2}$
}

AdDitional INDEX wORDs. best management practices, nitrogen, phosphorus, fertilizer, irrigation, water quality

SUMMARY. Florida citrus (Citrus spp.) producers must improve water and nutrient use efficiency to remain sustainable as they face increasing urbanization, plant disease, and environmental awareness. Producers have traditionally used watersoluble nitrogen $(\mathrm{N})$ and phosphorus fertilizer sources with calendar-based irrigation, but they are slowly integrating enhanced efficiency fertilizers into nutrient management plans and converting to sensor or evapotranspiration-based irrigation scheduling. Recent research has improved the understanding of the citrus grove $\mathrm{N}$ budget, which has led to development of appropriate best management practices (BMPs) that will maintain production while protecting the environment. BMPs that have been shown to decrease $\mathrm{N}$ loss to groundwater include applying the appropriate fertilizer rate, splitting fertilizer applications, converting to fertigation, and improving irrigation scheduling.

$\mathrm{F}$ lorida citrus producers are attempting to maintain economical production and protect the surrounding environment from excessive nutrients in the face of increasing fertilizer costs, new disease outbreaks, and conversion of grove land to urban uses. To remain sustainable, the industry must improve nitrogen $(\mathrm{N})$ and phosphorus (P) fertilizer use efficiency because total maximum daily load implementation will limit $\mathrm{N}$ and/or P loading in watersheds where citrus is grown. The objectives of this article are to describe how $\mathrm{N}$ and $\mathrm{P}$ are currently managed to grow citrus in Florida, to provide an accounting of the citrus $\mathrm{N}$ budget, to describe $\mathrm{N}$ leaching and $P$ runoff from citrus production, to outline best management practices to improve citrus nutrient management efficiency, and to look ahead to the future of citrus nutrient management.

\section{Typical nitrogen and phosphorus management practices used to produce Florida citrus}

Citrus response to $\mathrm{N}$ fertilization is strong because $\mathrm{N}$ has more influence on tree growth, appearance, fruit production, and fruit quality than any other nutrient [Alva et al., 2006a;

${ }^{1}$ Soil and Water Science Department, University of Florida, 2169 McCarty Hall, P.O. Box 110290, Gainesville, FL 32611

${ }^{2}$ Citrus Research and Education Center, 700 Experiment Station Road, Lake Alfred, FL 33440

${ }^{3}$ Corresponding author. E-mail: obreza@ufl.edu.
Schumann et al., 2003 (Fig. 1)]. When $\mathrm{N}$ is in short supply, growth and yield are limited and the foliage becomes pale green or yellow. In contrast to $\mathrm{N}$, a positive tree response to $\mathrm{P}$ fertilizer is rarely observed in Florida (Obreza, 2000). Most mature Florida citrus groves contain sufficient residual $\mathrm{P}$ that accumulated from previous fertilizer applications (Tucker et al., 1990), so regular P fertilizer application is usually not necessary.

Florida citrus growers use mostly water-soluble fertilizers that are bulkblended into $\mathrm{N}$-potassium $(\mathrm{K})$ mixes or complete $\mathrm{N}-\mathrm{P}-\mathrm{K}$ fertilizers, often including micronutrients. Solid fertilizers are applied with conventional spreading equipment and are sometimes applied by hand to young trees. Solid, rapidly available $\mathrm{N}$ sources commonly applied to citrus include ammonium nitrate and ammonium sulfate. Urea is often combined with ammonium nitrate to make fluid fertilizers that are applied as suspensions or with irrigation water (fertigation). Other less common $\mathrm{N}$ sources include potassium nitrate and calcium nitrate.

Phosphorus fertilizer is applied to citrus at much lower rates compared with $\mathrm{N}$, and in many cases, it is not applied at all if soil test $\mathrm{P}$ is high. When $\mathrm{P}$ fertilizer is applied, growers choose among concentrated superphosphate, monoammonium phosphate, and diammonium phosphate solid forms. Fluid forms of $\mathrm{P}$ include ammonium polyphosphate and phosphoric acid.

Enhanced efficiency fertilizers (EEFs) are fertilizer products with characteristics that minimize the potential of nutrient losses to the environment compared with "reference soluble" products (Hall, 2006). Fertilizers of this type that are integrated into citrus nutrient management programs are mostly $\mathrm{N}$ sources, but some contain $\mathrm{P}$ and $\mathrm{K}$ as well. Enhanced efficiency fertilizers applied to citrus include urea formaldehyde (ureaform, methylene urea), isobutylidene diurea, Organiform ${ }^{\circledR}$ (leather tankage bonded with methylene urea; Spectrum Brands, Atlanta, GA), and several coated materials such as sulfur-coated urea. The standard ("reference") release rate of EEFs is controlled by their chemical or physical characteristics, but nutrient release is also influenced by soil temperature or water content.

Some citrus producers apply organic-based fertilizers like animal manures, biosolids, and municipal composts. Nutrient release from these materials occurs during biological degradation. The rate at which nutrients become available varies widely depending on composition, age, application method, and climatic condition (Obreza and Ozores-Hampton, 2000).

\begin{tabular}{llll}
\hline $\begin{array}{l}\text { Units } \\
\begin{array}{l}\text { To convert U.S. to SI, } \\
\text { multiply by }\end{array}\end{array}$ & U.S. unit & SI unit & $\begin{array}{l}\text { To convert SI to U.S., } \\
\text { multiply by }\end{array}$ \\
\hline 0.4047 & acre(s) & $\mathrm{ha}$ & 2.4711 \\
9.3540 & gal/acre & $\mathrm{L} \cdot \mathrm{ha}^{-1}$ & 0.1069 \\
2.54 & inch(es $)$ & $\mathrm{cm}$ & 0.3937 \\
25.4 & inch $(\mathrm{es})$ & $\mathrm{mm}$ & 0.0394 \\
0.4536 & lb & $\mathrm{kg}$ & 2.2046 \\
1.1209 & $\mathrm{lb} / \mathrm{acre}$ & $\mathrm{kg} \cdot \mathrm{ha}^{-1}$ & 0.8922 \\
28.3495 & $\mathrm{oz}$ & $\mathrm{g}$ & 0.0353 \\
1 & $\mathrm{ppm}$ & $\mathrm{mg} \cdot \mathrm{kg}^{-1}$ & 1 \\
1 & $\mathrm{ppm}$ & $\mathrm{mg} \cdot \mathrm{L}^{-1}$ & 1 \\
2.2417 & ton/acre & $\mathrm{t} \cdot \mathrm{ha}^{-1}$ & 0.4461
\end{tabular}


Annual recommended $\mathrm{N}$ fertilizer rates for citrus depend on tree age for nonbearing trees and on fruit type and expected fruit production for bearing trees (Obreza and Morgan, 2008). The maximum $\mathrm{N}$ recommendation for a mature, high-yielding sweet orange (Citrus sinensis) grove is $250 \mathrm{lb} /$ acre, whereas the average recommendation is usually $\approx 180 \mathrm{lb} /$ acre. The recommendation to apply $\mathrm{P}$ fertilizer depends on soil and leaf tissue test results (Obreza and Morgan, 2008). To justify applying $P$, the soil should test medium or lower (30 ppm or less Mehlich 1-extractable $\mathrm{P}$ ) or the tissue $\mathrm{P}$ concentration of 6-month-old spring growth leaves should be less than $0.12 \%$. A basic dry fertilizer application timing schedule for citrus divides the total annual requirement into three equal increments applied in March, May, and September. Applying fertilizer during the summer rainy season is avoided. Fertigation schedules divide the annual fertilizer rate into 10 to 20 doses per year.

Solid fertilizer spreaders apply dry materials directly over the root zone, avoiding the row middle. For small trees, manual or electronic spreader adaptations deliver fertilizer rates accurately to the root zone while leaving out the nonrooted area between rows and spaces with missing trees. Fertigation with microsprinklers or drippers places small, frequent nutrient doses in the wetted

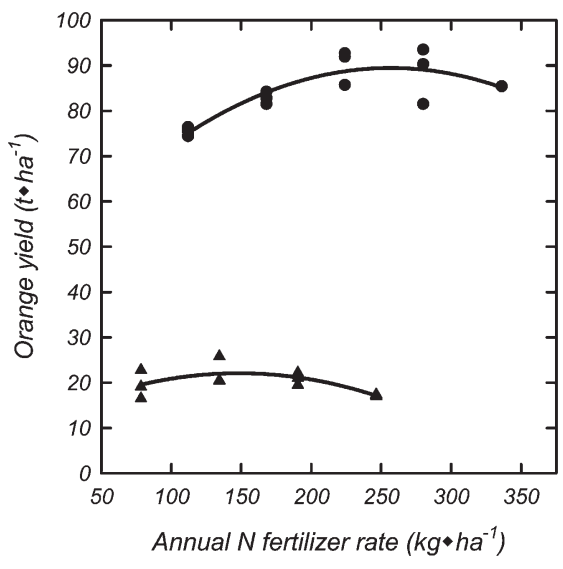

Fig. 1. The nature of sweet orange fruit yield response to nitrogen $(\mathrm{N})$ fertilizer in low-producing and high-producing Florida groves (data from Schumann et al., 2003 and Alva et al., 2006a as cited in Obreza and Morgan, 2008); $1 \mathrm{t} \cdot \mathrm{ha}^{-1}=0.4461 \mathrm{ton} / \mathrm{acre} ; \mathrm{l} \mathrm{kg} \cdot \mathrm{ha}^{-1}=$ $0.8922 \mathrm{lb} /$ acre. area where the most active roots are located. This technique can increase fertilizer use efficiency and reduce leaching. Application cost is lower than that of dry or foliar fertilizer application because fertilization is incorporated with normal irrigation. A microirrigation system must be properly maintained such that water and fertilizer are applied uniformly to effectively fertigate citrus trees.

Suspension fertilizers are applied with an herbicide boom that places the fertilizer directly over the root zone. Foliar fertilizers are applied to citrus trees with an airblast sprayer in 100 to $250 \mathrm{gal} / \mathrm{acre}$ of water. The goal of airblast spraying is to replace the air contained within the tree canopy with spray-laden air. Foliar application is not intended to replace soil-applied fertilizers, but it can provide $\mathrm{N}$ and $\mathrm{P}$ to the tree on a timely basis during critical stages of growth, flowering, and fruit development.

Variable rate technology (VRT) solves the problem of fertilizer waste that occurs when nutrients are uniformly applied to a grove with varying tree sizes. For example, immature trees or resets should not receive the same fertilization as mature trees, and gaps in the grove should not receive any fertilizer. With VRT, fertilizer is applied on a tree-by-tree basis using automatic sensors to determine the rate according to tree height or canopy density (Schumann et al., 2006). Fertilizer use in highly variable citrus groves has been reduced by as much as $40 \%$ using VRT. In addition to reducing production costs, the risk of nutrient loss is minimized.

\section{Water management in Florida citrus production}

Most Florida citrus groves are irrigated by microsprinkler systems that apply water efficiently and precisely. A small minority of groves are irrigated by drip systems or seepage irrigation (water table control on poorly drained soils only). Although annual citrus potential evapotranspiration $(\mathrm{ET})$ is $\approx 45$ inches, the annual irrigation requirement is 15 to 17 inches depending on rainfall amount and distribution.

Proper irrigation scheduling applies the required volume of water to a citrus grove at the appropriate time based on tree need, soil properties, and weather conditions. Scheduling methods include experience, the calendar method (e.g., 0.8 inch every fourth day during the dry season), monitoring soil water status, and calculating a water budget. Water budgeting for irrigation scheduling is described by Morgan and Hanlon (2007).

Continuously measuring soil moisture with modern technology (e.g., time-domain reflectometry sensors or capacitance probes) is the most accurate irrigation scheduling method. For example, a multilevel capacitance probe can be used to irrigate such that nutrient leaching is minimized. The four lines in Figure 2 represent soil moisture content 4,8 , 12 , and 20 inches deep in a commercial citrus grove. The $\mathrm{x}$-axis shows a 16-d time period separated into 2 -d increments. The effect of irrigation is easily observed as sharp increases in soil moisture at the top three depths. However, the first irrigation increased

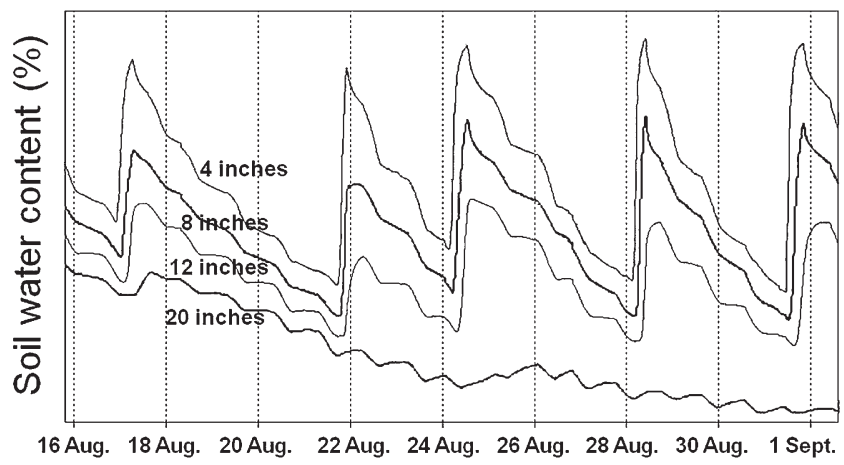

Fig. 2. Continuous monitoring of soil moisture at 4-, 8-, 12-, and 20-inch (10.2, $20.3,30.5$, and $50.8 \mathrm{~cm}$ ) depths in the soil by a multilevel capacitance probe installed in the root zone of a mature citrus tree improves water use efficiency and minimizes nutrient leaching. 
soil moisture at the 20 -inch depth as well, which is below the zone of highest root density. Because the goal was to keep the irrigation water in the top 18 inches of soil, the producer reduced the duration of subsequent irrigations. The steadily decreasing water content at the 20 -inch depth during the next 2 -week period showed that the grower had attained optimum irrigation water management.

Central Florida ridge groves are naturally well drained, but flatwood groves must be artificially drained to lower the shallow water table after heavy rain. There are two drainage management philosophies, uncontrolled and controlled. With uncontrolled drainage, water flow control points in the drainage network are opened as wide as possible to drain the grove quickly. With controlled drainage, flow points are opened only partially, which allows the grove to drain more slowly. This philosophy keeps a base water table closer to the citrus root zone for a longer period of time and may delay the onset of irrigation. The potential for nutrient loss is considerably lower with controlled drainage.

\section{Nutrient budgets}

In the Florida citrus production system, the major component of the annual nutrient removal from the tree-soil system is the fruit. The average amount of $\mathrm{N}, \mathrm{P}$, and $\mathrm{K}$ removed

Table 1. Citrus nitrogen $(\mathrm{N})$ budget estimation and simulation by the LEACHM model (Wagenet and Hutson, 1989) for a greater than 20-year-old, very high-producing sweet orange grove on deep sandy soil with optimum irrigation (Alva et al., 2006b).

\begin{tabular}{|c|c|c|}
\hline \multirow[b]{3}{*}{ Input } & N budget & Simulation \\
\hline & \multicolumn{2}{|c|}{$\left(\mathrm{kg} \cdot \mathrm{ha}^{-1} \mathrm{~N} \text { per yr }\right)^{\mathrm{z}}$} \\
\hline & & \\
\hline Fertilizer $\mathrm{N}$ applied & 280 & 280 \\
\hline Organic residue mineralization & 90 & 78 \\
\hline Atmospheric deposition & 11 & - \\
\hline Nonsymbiotic $\mathrm{N}$ fixation & 6 & - \\
\hline Initial soil profile $\mathrm{N}$ & 20 & 25 \\
\hline Total & 407 & 383 \\
\hline \multicolumn{3}{|l|}{ Plant uptake } \\
\hline $\begin{array}{l}\text { Total } \mathrm{N} \text { in fruit }\left[115 \mathrm{t}^{\cdot \mathrm{ha}^{-1}}\right. \\
\quad(51.5 \text { tons/acre }) \text { yield }]\end{array}$ & 179 & $\begin{array}{l}\text { LEACHM does not partition } \\
\mathrm{N} \text { by tree component. }\end{array}$ \\
\hline Spring growth & 34 & \\
\hline Fibrous roots & 45 & \\
\hline Storage & 28 & \\
\hline Total & 286 & 281 \\
\hline \multicolumn{3}{|l|}{ Estimated losses/residual soil $\mathrm{N}$} \\
\hline Gaseous loss & 43 & 24 \\
\hline Drainage (leaching) below the root zone & - & 59 \\
\hline Soil residual $\mathrm{N}$ & 15 & 19 \\
\hline Total & 57 & 102 \\
\hline Unaccounted N (likely to be leached) & 64 & \\
\hline
\end{tabular}

${ }^{2} 1 \mathrm{~kg} \cdot \mathrm{ha}^{-1}=0.8922 \mathrm{lb} /$ acre . per 100 field boxes $(900 \mathrm{lb})$ of harvested sweet orange fruit is $12.1,1.7$, and $14.5 \mathrm{lb}$, respectively (Mattos et al., 2003a; Paramasivam et al., 2000). Nitrogen budgets for mature, high-producing Florida citrus groves have been estimated using an accounting method (comparing inputs versus outputs) and simulated using the LEACHM model (Alva et al., 2006b; Paramasivam et al., 2002; Tables 1 and 2). The production system described in Table 1 was evaluated for an entire year. Nitrogen fertilizer application constituted $\approx 70 \%$ of the total $\mathrm{N}$ input. Tree $\mathrm{N}$ uptake was also equal to $\approx 70 \%$ of total $\mathrm{N}$ input. Approximately $63 \%$ of tree N uptake was allocated to fruit production. The amount of $\mathrm{N}$ lost from the system was $\approx 62 \mathrm{~kg} \cdot \mathrm{ha}^{-1}$ per year, or $\approx 16 \%$ of the total $\mathrm{N}$ input. The production system shown in Table 2 was evaluated for 6 weeks after four rates of $\mathrm{N}$ fertilizer were applied. The LEACHM model estimated that from $21 \%$ to $36 \%$ of the applied $\mathrm{N}$ fertilizer leached.

Measurement of $\mathrm{N}$ weight and distribution throughout sweet orange trees of various sizes showed that the mature fruit crop of a large tree contained approximately one-fourth of the total $\mathrm{N}$, whereas the leaf canopy contained slightly more [Morgan et al., 2006 (Table 3)]. The remaining $\mathrm{N}$ was distributed between the wood and roots. As a small sweet orange tree grows into a large tree, the proportion of $\mathrm{N}$ in the branches increases from $\approx 11 \%$ to $28 \%$ of total nonfruit crop $\mathrm{N}$ in the tree, whereas the proportion in the leaf canopy decreases from $\approx 45 \%$ to $37 \%$ and the proportion in the trunk decreases from $\approx 6 \%$ to $2 \%$ of total nonfruit $\mathrm{N}$ (Morgan et al., 2006).

Citrus tree residues (leaves, twigs, fibrous roots) decompose quickly

Table 2. Nitrogen $(\mathrm{N})$ balance at the end of a 6-week period as simulated by the LEACHM model (Wagenet and Hutson, 1989) for a single application of soluble $\mathrm{N}$ fertilizer applied at four rates to a sweet orange grove (Paramasivam et al., 2002).

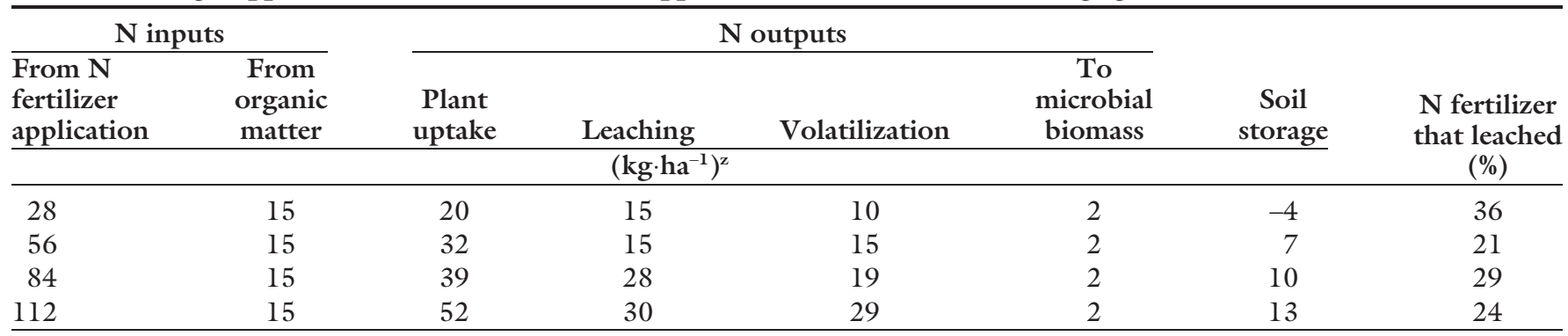

${ }^{2} 1 \mathrm{~kg} \cdot \mathrm{ha}^{-1}=0.8922 \mathrm{lb} / \mathrm{acre}$. 
(mostly within 1 to 2 years after deposition) as a result of Florida's warm and humid climate (Mattos et al., 2003b). Mineralized nutrients return to the soil in plant-available form. In a residue mineralization study, the amount of $\mathrm{N}$ released from grove floor residue and dead roots during a 1 -year period varied from 39 to 84 $\mathrm{kg} \cdot \mathrm{ha}^{-1}$ in a young grove ( 4 years old) and from 123 to $151 \mathrm{~kg} \cdot \mathrm{ha}^{-1}$ in a mature grove (20 years old) (Dou et al., 1997).

Nitrogen leaching losses from a mature sweet orange grove were calculated by analyzing soil solution $\mathrm{N}$ concentration and estimating the water flux that moved below the root zone during a 2-year period [Paramasivam et al., 2001 (Table 4)]. Nitrogen leaching estimates ranged between almost none to $\approx 34 \mathrm{~kg} \cdot \mathrm{ha}^{-1}$

Table 3. Example of the biomass and nitrogen $(\mathrm{N})$ distribution in a mature sweet orange tree with a dry weight of $124 \mathrm{~kg}(273.4 \mathrm{lb}) .^{\mathrm{z}}$

\begin{tabular}{lcc}
\hline & $\begin{array}{c}\text { Total tree } \\
\text { dry biomass }\end{array}$ & $\begin{array}{c}\text { Total N } \\
\text { in tree }\end{array}$ \\
\cline { 2 - 3 } & \multicolumn{2}{c}{$\mathbf{( \% )}$} \\
\hline Leaves & 10 & 28 \\
Twigs and & 40 & 24 \\
$\quad$ branches & & 2 \\
Trunk & 3 & 20 \\
Roots & 23 & 26 \\
Fruit & 24 &
\end{tabular}

${ }^{2}$ The total $\mathrm{N}$ content of the tree, including a $196-\mathrm{kg}$ $(432.1 \mathrm{lb})$ fresh weight fruit crop, was $1.0 \mathrm{~kg}(2.20 \mathrm{lb})$ (Morgan et al., 2006).

Table 4. The influence of nitrogen $(\mathrm{N})$ fertilizer source and rate on estimated nitrate- $\mathrm{N}\left(\mathrm{NO}_{3}-\mathrm{N}\right)$ leached below the root zone of a mature sweet orange grove on a well-drained soil with optimal irrigation scheduling (Paramasivam et al., 2001).

\begin{tabular}{|c|c|c|c|c|c|}
\hline \multirow{5}{*}{ N source } & \multirow{4}{*}{$\begin{array}{c}\mathrm{N} \text { rate }\left(\mathrm{kg} \cdot \mathrm{ha}^{-1}\right. \\
\text { per year })^{\mathrm{z}}\end{array}$} & \multicolumn{4}{|c|}{ Yr } \\
\hline & & 1994 & 1995 & 1994 & 1995 \\
\hline & & \multicolumn{4}{|c|}{ Estimated $\mathrm{NO}_{3}-\mathrm{N}$ leached } \\
\hline & & \multicolumn{2}{|c|}{$\left(\mathrm{kg} \cdot \mathrm{ha}^{-1}\right)$} & \multicolumn{2}{|c|}{ (\% of $\mathrm{N}$ applied) } \\
\hline & 112 & 10 & 12 & 9 & 11 \\
\hline & 168 & 11 & 13 & 7 & 8 \\
\hline & 224 & 15 & 13 & 7 & 6 \\
\hline & 280 & 22 & 21 & 8 & 8 \\
\hline \multirow[t]{4}{*}{ Fertigation } & 112 & 17 & 18 & 15 & 16 \\
\hline & 168 & 18 & 25 & 11 & 15 \\
\hline & 224 & 24 & 30 & 11 & 14 \\
\hline & 280 & 29 & 35 & 10 & 12 \\
\hline \multirow[t]{3}{*}{ Controlled-release } & 56 & 1 & 1 & 2 & 2 \\
\hline & 112 & 1 & 3 & 1 & 3 \\
\hline & 168 & 3 & 8 & 2 & 5 \\
\hline
\end{tabular}

${ }^{\mathrm{z}} \mathrm{l} \mathrm{kg} \cdot \mathrm{ha}^{-1}=0.8922 \mathrm{lb} /$ acre. depending on fertilizer source and rate. Fertilizer source had the greatest effect on $\mathrm{N}$ leaching in the following order: fertigation $>$ dry granular $>$ controlled release. The relative amount of $\mathrm{N}$ leached as a percentage of $\mathrm{N}$ rate applied varied between $1 \%$ and $16 \%$. The authors of this study explained that more $\mathrm{N}$ leaching occurred with fertigation compared with dry granular application "purely because of unexpected prolonged irrigation or unexpected high rainfall following certain fertigation events in both years."

Nitrogen use efficiency (NUE), defined as the amount of $\mathrm{N}$ fertilizer taken up by citrus trees divided by the amount applied, has been measured for young sweet orange trees using ${ }^{15} \mathrm{~N}$-labeled fertilizer [Mattos et al., 2003c (Table 5)]. Ammonium nitrate had a substantially higher NUE (40\%) compared with urea $(28 \%)$, probably because $\mathrm{N}$ was lost from urea by volatilization before it could be taken up. Under the same environmental conditions, ammonium nitrate applied to mature trees would probably have higher NUE as a result of a larger root system.

Citrus trees take up much less $\mathrm{P}$ than $\mathrm{N}$. On an atomic basis, the $\mathrm{N}: \mathrm{P}$ ratio in a citrus tree is $\approx 20: 1$ (Mattos et al., 2003a). Unlike $\mathrm{N}$, applied $\mathrm{P}$ fertilizer can be retained to an extent by most Florida citrus soils. A survey of 122 Florida citrus production blocks planted on poorly drained soils found that the Mehlich 1 soil test
$\mathrm{P}$ averaged $55 \mathrm{ppm}$ (interpreted as "high") in the top 6 inches of soil (Tucker et al., 1990). In another study, the mean Mehlich 1-extractable $\mathrm{P}$ of 118 soil samples from a wide range of Florida citrus groves was 103 ppm ("very high") (Alva, 1993).

Because most mature Florida citrus groves contain sufficient residual $\mathrm{P}$ from previous fertilizer applications, regular $\mathrm{P}$ fertilizer application is not necessary. The need for $\mathrm{P}$ fertilizer in established groves is determined by soil and leaf analysis. Most previously noncultivated soils used for new citrus plantings are naturally low in $P$, so fertilizer application may be needed for the first few years until $\mathrm{P}$ accumulates in the root zone.

\section{Nitrogen leaching and phosphorus runoff losses from citrus production}

A 7-year study conducted in central Florida evaluated the effect of $\mathrm{N}$ fertilization best management practices (BMPs) on groundwater quality beneath five citrus groves (Alva et al., 1998, 2003; Lamb et al., 1999). One (Grove A) was on poorly drained soil and four (Groves B through E) were on well-drained soils (i.e., soils most vulnerable to leaching). The nitrate$\mathrm{N}\left(\mathrm{NO}_{3}-\mathrm{N}\right)$ concentration was monitored in the surficial portion of the aquifer for 2 years prior and 5 years after BMP implementation. The BMPs included appropriate $\mathrm{N}$ rates, conversion from dry fertilizer application to fertigation (three groves), inclusion of slow-release fertilizer (one

Table 5. Recovery of labeled nitrogen $(\mathrm{N})$ fertilizer by 6 -year-old sweet orange trees $280 \mathrm{~d}$ after it was applied. $^{\mathrm{z}}$

\begin{tabular}{|c|c|c|}
\hline \multirow{3}{*}{$\begin{array}{l}\text { Tree } \\
\text { component }\end{array}$} & \multicolumn{2}{|c|}{$\mathbf{N}$ fertilizer source } \\
\hline & $\begin{array}{l}\text { Ammonium } \\
\text { nitrate }\end{array}$ & Urea \\
\hline & \multicolumn{2}{|c|}{ (\% of $\mathrm{N}$ applied) } \\
\hline Leaves & 9 & 5 \\
\hline Twigs & 5 & 3 \\
\hline Trunk & 1 & 1 \\
\hline $\begin{array}{c}\text { Roots (fibrous }+ \\
\text { woody }+ \text { tap) }\end{array}$ & 7 & 5 \\
\hline $\begin{array}{l}\text { Fruit } \\
\qquad(9 \text { months old })\end{array}$ & 18 & 10 \\
\hline Total & 40 & 24 \\
\hline
\end{tabular}


grove), and optimum irrigation scheduling (Table 6). Groundwater $\mathrm{NO}_{3}-\mathrm{N}$ concentration beneath the grove on poorly drained soil was below $2 \mathrm{mg} \cdot \mathrm{kg}^{-1}$ at the start of the study. No change was made to the $\mathrm{N}$ fertilization program, and groundwater $\mathrm{NO}_{3}-\mathrm{N}$ actually decreased slightly 6 years later. Groundwater $\mathrm{NO}_{3}-\mathrm{N}$ concentration beneath the groves on well-drained soils steadily decreased with time after BMP implementation (Table 6). Grove B showed the most improvement, where groundwater $\mathrm{NO}_{3}-\mathrm{N}$ decreased by more than two-thirds in 6 years.

A 2-year study was conducted on Florida's lower east coast to evaluate annual loads of various $\mathrm{P}$ forms in runoff water from seven citrus groves on poorly drained soils. Phosphorus fertilizer was applied to all groves regardless of soil test $\mathrm{P}$. The amount of total $\mathrm{P}$ runoff that occurred in a 2 -year period varied between 0.8 and $8.3 \mathrm{~kg} \cdot \mathrm{ha}^{-1}$ [He et al., 2006 (Table 7)]. For all groves, more than half of the total $\mathrm{P}$ in runoff was in dissolved form. No clear relationship between the amount of $\mathrm{P}$ in runoff and $\mathrm{P}$ fertilizer rate, water-extractable soil $\mathrm{P}$, or soil test P (Mehlich 1) was observed. This result emphasizes that the factors affecting off-site $\mathrm{P}$ movement from citrus groves are numerous and complex.

\section{Monitoring citrus tree nutrition}

Useful soil analysis for citrus includes measurement of organic matter, $\mathrm{pH}$, and extractable $\mathrm{P}$, calcium, and magnesium. These data help producers formulate and improve their fertilization programs. Soil analysis is particularly useful when trends across several consecutive years are observed, but soil analysis should not be relied on alone to formulate a fertilizer program or diagnose a nutritional problem.

University of Florida-Institute of Food and Agricultural Sciences soil test interpretations for P (Obreza and Morgan, 2008) were established from experiments with annual field and vegetable crops conducted for many years. Soil test calibration work with Florida citrus trees suggests that the current Florida interpretations are suitable for citrus (Obreza et al., 2008). Citrus leaf analysis is used to detect problems and adjust fertilizer programs for any nutrient because leaf concentrations are the most accurate indicator of fruit crop nutritional status. Because citrus is a perennial plant, it is its own best indicator of appropriate fertilization. Sampling guidelines should be followed precisely to ensure that analytical results are meaningful. Laboratory results are interpreted by comparing values with leaf analysis standards (Obreza and Morgan, 2008) that are based on long-term, worldwide field observations and experiments.

Citrus tree size (canopy height and volume) can be measured remotely using an ultrasonic sensor system, whereas tree position within the grove can be pinpointed with a differential global positioning satellite system. These data are processed by a computer program to create a canopy volume map. Because citrus yield is directly related to canopy volume, this map helps growers make decisions about long-term management. For example, a grove with a wide range of canopy volumes can be expected to have a considerable range in yield. Managing for canopy volume variability could improve yields and reduce environmental impacts of fertilizers.

Citrus yield maps can be produced by combining automatic harvest tub position logger data with global positioning satellite technology. The number of tubs per unit grove area can be used to identify both high and low production sites.

Table 6. Nitrate-nitrogen $\left(\mathrm{NO}_{3}-\mathrm{N}\right)$ concentrations in surficial groundwater beneath five Florida sweet orange groves 2 years before and 5 years after implementing $\mathrm{N}$ fertilizer best management practices (BMPs) that included optimum irrigation scheduling. ${ }^{\mathrm{z}}$

\begin{tabular}{|c|c|c|c|}
\hline \multicolumn{2}{|c|}{ Pre-BMP (1993-1994) } & \multicolumn{2}{|c|}{ Post-BMP (1995-1999) } \\
\hline $\begin{array}{l}\text { Grove } \mathrm{N} \text { fertilizer } \\
\text { management }^{\mathrm{y}}\end{array}$ & $\begin{array}{l}\mathrm{N} \text { concn in groundwater, } \\
1993\left(\mathrm{mg} \cdot \mathrm{L}^{-1} \mathrm{NO}_{3}-\mathrm{N}\right)^{\mathrm{y}}\end{array}$ & $\begin{array}{l}\text { Grove } \mathrm{N} \text { fertilizer } \\
\text { management }\end{array}$ & $\begin{array}{l}\mathrm{N} \text { concn in groundwater, } \\
1999\left(\mathrm{mg} \cdot \mathrm{L}^{-1} \mathrm{NO}_{3}-\mathrm{N}\right)\end{array}$ \\
\hline $\begin{array}{l}\text { Soluble } \mathrm{N} \text { fertilizer; } 140 \mathrm{~kg} \cdot \mathrm{ha}^{-1} \\
\text { per year in two dry applications }\end{array}$ & 1.5 & $\begin{array}{l}\text { Soluble } \mathrm{N} \text { fertilizer; } 140 \mathrm{~kg} \cdot \mathrm{ha}^{-1} \\
\text { per year in two dry applications }\end{array}$ & 0.5 \\
\hline \multicolumn{4}{|c|}{ Grove B } \\
\hline \multicolumn{4}{|c|}{ Grove $C$} \\
\hline $\begin{array}{l}\text { Soluble } \mathrm{N} \text { fertilizer; } 202 \mathrm{~kg} \cdot \mathrm{ha}^{-1} \\
\text { per year in two to three dry }\end{array}$ & 7.5 & $\begin{array}{l}\text { Soluble } \mathrm{N} \text { fertilizer; } 172 \mathrm{~kg} \cdot \mathrm{ha}^{-1} \\
\text { per year in } 18 \text { fertigations }\end{array}$ & 2.5 \\
\hline $\begin{array}{l}\text { Soluble N fertilizer; } 202 \mathrm{~kg} \cdot \mathrm{ha}^{-1} \text { per } \\
\text { year in three dry applications }\end{array}$ & 12.0 & $\begin{array}{l}\text { ove } E \\
\text { Soluble } \mathrm{N} \text { fertilizer; } 179 \mathrm{~kg} \cdot \mathrm{ha}^{-1} \\
\quad \text { per year in } 18 \text { fertigations }\end{array}$ & 9.0 \\
\hline
\end{tabular}

${ }^{\mathrm{z}}$ Grove A was on poorly drained soil, and Groves B through E were on well-drained soil (Lamb et al., 1999).

${ }^{\mathrm{y}} \mathrm{l} \mathrm{kg} \cdot \mathrm{ha}^{-1}=0.8922 \mathrm{lb} /$ acre, $1 \mathrm{mg} \cdot \mathrm{L}=1 \mathrm{ppm}$. 
Table 7. Annual phosphorus (P) fertilizer rates, water and Mehlich 1 soil test $P$, and total $P(T P)$, total dissolved $P$ (TDP), and ortho $P(O P)$ loads in runoff water from seven citrus groves on Florida's lower east coast during 2001 and 2002 (He et al., 2006).

\begin{tabular}{|c|c|c|c|c|c|c|}
\hline \multirow[b]{3}{*}{ Grove } & \multirow{3}{*}{$\begin{array}{l}\text { P fertilizer } \\
\text { application } \\
\left(\mathrm{kg} \cdot \mathrm{ha}^{-1}\right. \\
\text { per } \mathrm{yr})^{\mathrm{z}}\end{array}$} & \multicolumn{2}{|c|}{ Soil analysis method } & \multicolumn{3}{|c|}{ P load in runoff water, $2001+2002$} \\
\hline & & $\begin{array}{c}\text { Water } \\
\mathbf{P}\end{array}$ & $\begin{array}{l}\text { Mehlich } \\
\text { 1-P }\end{array}$ & TP & TDP & OP \\
\hline & & \multicolumn{2}{|c|}{$\left(\mathrm{mg} \cdot \mathrm{L}^{-1}\right)^{\mathrm{z}}$} & \multicolumn{3}{|c|}{$\left(\mathrm{kg} \cdot \mathrm{ha}^{-1}\right)$} \\
\hline 1 & 37 & 4 & 38 & 1.3 & 0.9 & 0.2 \\
\hline 2 & 38 & 5 & 34 & 0.8 & 0.6 & 0.2 \\
\hline 3 & 38 & 3 & 15 & 3.8 & 1.9 & 1.5 \\
\hline 4 & 38 & 2 & 13 & 4.6 & 2.8 & 1.5 \\
\hline 5 & 37 & 8 & 60 & 8.3 & 7.2 & 6.0 \\
\hline 6 & 24 & 1 & 9 & 3.0 & 2.0 & 0.9 \\
\hline 7 & 16 & 7 & 57 & 5.0 & 3.8 & 2.7 \\
\hline
\end{tabular}

${ }^{2} 1 \mathrm{~kg} \cdot \mathrm{ha}^{-1}=0.8922 \mathrm{lb} / \mathrm{acre}, 1 \mathrm{mg} \cdot \mathrm{L}=1 \mathrm{ppm}$.

Fertilizer savings can be realized by applying the rate of fertilizer needed by the trees based on their yield with a variable rate fertilizer applicator.

The high water table present in most poorly drained citrus soils can significantly affect tree water relations. To avoid off-site movement of nutrients, water table level should be monitored and maintained within an optimal zone (Boman and Obreza, 2002). A water table observation well is a perforated pipe buried vertically in the ground that permits groundwater to rise and fall inside it just as it does in the adjacent soil. An observation well with a simple float indicator provides rapid evaluation of shallow water table depths. This well is an excellent tool for determining when to irrigate or when the water table is too high. The goal of water table management is to maintain the water table at a level just below the root zone but not high enough to cause root damage. Upward water flux from a shallow water table resulting from capillary action opposes leaching by moving soluble nutrients in an upward direction against gravity.

\section{Best management practices to improve water and nutrient use efficiency}

Most BMPs are simple, commonsense, "good housekeeping" practices that producers already use. In abbreviated form, they are (Florida Dept. of Agriculture and Consumer Services, 2000):

- Educate and train field operators about BMPs;

- Develop a nutrient management plan;
- Use tissue and soil analysis to make fertilization decisions;

- Use appropriate application equipment;

- Properly calibrate and maintain application equipment;

- Apply fertilizers to target sites;

- Avoid high-risk fertilizer applications (such as during the rainy season);

- Store fertilizer to prevent contamination of nearby water sources;

- Collect spilled fertilizer and apply it as normal;

- Use caution when loading near ditches, canals, and wells;

- Use multiple fertilizer loading and transfer sites;

- Use backflow prevention devices on water-filling systems;

- Split fertilizer applications throughout the growing season;

- Use erosion-control practices to minimize soil loss and runoff;

- Try to wet only the root zone when irrigating;

- Add organic matter to the soil whenever possible;

- Plug wells that are not in use; and

- Use appropriate fertilizer sources and formulations.

\section{The future of Florida citrus nutrient management}

In the next 5 years, the citrus industry should focus its efforts on 1 ) improving irrigation management by implementing sensor or ET-based irrigation; 2) incorporating EEFs into nutrient management plans; and 3) expanding the use of VRT. Strategic areas of future citrus research that have the greatest chance to improve the quality of Florida waters are 1) sensor-based fertilizer application; 2) verifying nutrient release curves for new EEFs; 3) linking soil moisture sensors or ET measurements to automated irrigation systems; and 4) investigating the long-term effect of citrus diseases and continued urban growth on nutrient management.

\section{Literature cited}

Alva, A.K. 1993. Comparison of Mehlich 3, Mehlich 1, ammonium bicarbonateDTPA, $1.0 \mathrm{M}$ ammonium acetate, and $0.2 \mathrm{M}$ ammonium chloride for extraction of calcium, magnesium, phosphorus, and potassium for a wide range of soils. Commun. Soil Sci. Plant Anal. 24:603-612.

Alva, A.K., S. Paramasivam, and W.D. Graham. 1998. Impact of nitrogen management practices on nutritional status and yield of Valencia orange trees and groundwater nitrate. J. Environ. Qual. 27:904-910.

Alva, A.K., S. Paramavisam, W.D. Graham, and T.A. Wheaton. 2003. Best nitrogen and irrigation management practices for citrus production in sandy soils. Water Air Soil Pollut. 143:139-154.

Alva, A.K., S. Paramasivam, T.A. Obreza, and A.W. Schumann. 2006a. Nitrogen best management practices for citrus trees. I. Fruit yield, quality, and leaf nutritional status. Scientia Hort. 107:233244.

Alva, A.K., S. Paramasivam, T.A. Obreza, and A.W. Schumann. 2006b. Nitrogen best management practices for citrus trees. II. Nitrogen fate, transport, and components of $\mathrm{N}$ budget. Scientia Hort. 109:223-233.

Boman, B.J. and T.A. Obreza. 2002. Water table measurement and monitoring, p. 208-216. In: B.J. Boman (ed.). Water and Florida citrus. Univ. Florida, Inst. Food Agr. Sci., Publ. SP 281.

Dou, H., A.K. Alva, and B.R. Khakural. 1997. Nitrogen mineralization from citrus tree residues under different production conditions. Soil Sci. Soc. Amer. J. 61:1226-1232.

Florida Dept. of Agriculture and Consumer Services. 2000. Water quality/ quantity BMPs for Indian River area citrus groves. 23 Apr. 2009. <http://www. floridaagwaterpolicy.com/PDF/Bmps/ Bmp_IndianRiverCitrus2000.pdf $>$.

Hall, B. 2006. Enhanced efficiency fertilizers: Labeling, regulation, \& monitoring. 23 Apr. 2009. <http://www.aapfco. org/AACO $\% 202006 / A A P F C O \% 20 S R \%$ 20Reg\%2006.ppt>. 
He, Z.L., M.K. Zhang, P.J. Stoffella, X.E. Yang, and D.J. Banks. 2006. Phosphorus concentrations and loads in runoff water under crop production. Soil Sci. Soc. Amer. J. 70:1807-1816.

Lamb, S.T., W.D. Graham, C.B. Harrison, and A.K. Alva. 1999. Impact of alternative citrus management practices on groundwater nitrate in the central Florida ridge. I. Field investigation. Trans. Amer. Soc. Agr. Eng. 42:1653-1668.

Mattos, D., Jr., J.A. Quaggio, H. Cantarella, and A.K. Alva. 2003a. Nutrient content of biomass components of Hamlin sweet orange trees. Scientia Agricola 60:155160.

Mattos, D., Jr., A.K. Alva, S. Paramasivam, and D.A. Graetz. 2003b. Nitrogen volatilization and mineralization in a sandy Entisol of Florida under citrus. Commun. Soil Sci. Plant Anal. 34:1803-1824.

Mattos, D., Jr., D.A. Graetz, and A.K. Alva. 2003c. Biomass distribution and nitrogen-15 partitioning in citrus trees on a sandy Entisol. Soil Sci. Soc. Amer. J. 67:555-563.

Morgan, K.T. and E.A. Hanlon. 2007. Improving citrus nitrogen uptake efficiency: Effective irrigation scheduling. Soil Water Sci. Dept., Florida Coop. Ext. Serv., Inst. Food Agr. Sci., Univ. Florida, Fact Sheet SL-247.
Morgan, K.T., J.M. Scholberg, T.A. Obreza, and T.A. Wheaton. 2006. Size, biomass and nitrogen relationships with sweet orange tree growth. J. Amer. Soc. Hort. Sci. 131:149-156.

Obreza, T.A. 2000. Managing phosphorus for maximum citrus yield and quality. Proc. Intl. Soc. Citriculture IX Congr. p. 330-333.

Obreza, T.A. and K.T. Morgan (eds.). 2008. Nutrition of Florida citrus trees. 2nd Ed. Soil Water Sci. Dept., Florida Coop. Ext. Serv., Inst. Food Agr. Sci., Univ. Florida, Publ. SL 253.

Obreza, T.A. and M. Ozores-Hampton. 2000. Management of organic amendments in Florida citrus production systems. Soil Crop Sci. Soc. Florida Proc. 59:22-27.

Obreza, T.A., R.E. Rouse, and K.T. Morgan. 2008. Managing phosphorus for citrus yield and fruit quality in developing orchards. HortScience 43: 2162-2166.

Paramasivam, S., A.K. Alva, A. Fares, and K.S. Sajwan. 2001. Estimation of nitrate leaching in an Entisol under optimum citrus production. Soil Sci. Soc. Amer. J. 65:914-921.

Paramasivam, S., A.K. Alva, A. Fares, and K.S. Sajwan. 2002. Fate of nitrate and bromide in an unsaturated zone of a sandy soil under citrus production. J. Environ. Qual. 31:671-681.

Paramasivam, S., A.K. Alva, K.H. Hostler, G.W. Easterwood, and J.S. Southwell. 2000. Fruit nutrient accumulation of four orange varieties during fruit development. J. Plant Nutr. 23:313-327.

Schumann, A.W., A. Fares, A.K. Alva, and S. Paramasivam. 2003. Response of 'Hamlin' orange to fertilizer source, annual rate, and irrigated area. Proc. Florida State Hort. Soc. 116:256-260.

Schumann, A.W., K.H. Hostler, S.M. Buchanon, and Q. Zaman. 2006. Relating citrus canopy size and yield to precision fertilization. Proc. Florida State Hort. Soc. 119:148-154.

Tucker, D.P.H., R.M. Davis, T.A. Wheaton, and S.H. Futch. 1990. A nutritional survey of southcentral, southwest, and east coast flatwoods citrus groves. Proc. Florida State Hort. Soc. 103:324327.

Wagenet, R.J. and J.L. Hutson. 1989. LEACHM: Leaching Estimation and Chemistry Model: A process based model of water and solute movement transformations, plant uptake and chemical reactions in the unsaturated zone. Continuum Vol. 2. Water Resources Inst., Cornell Univ., Ithaca, NY. 